\title{
E-ISSN 2549-8703 I P-ISSN 2302-7282

\section{ANALISIS POLA PERTUMBUHAN DAN PENDEKATAN DNA BARCODING UNTUK IDENTIFIKASI Turbo stenogyrus P. Fischer, 1873 (MOLLUSCA: GASTROPODA)}

\section{ANALISYS OF GROWTH PATTERNS AND DNA BARCODING APPROACH TO IDENTIFY Turbo stenogyrus P. Fischer, 1873 (MOLLUSCA: GASTROPOD)}

\author{
Dandi Saleky $^{1}$, Simon P.O Leatemia ${ }^{2)}$, Thomas F. Pattiasina ${ }^{2)}$, Isma ${ }^{2)}$, Rosa D. Pangaribuan ${ }^{1}$, Marius A. \\ Welliken $^{1}$, Edy H.P Melmambessy ${ }^{1)}$, Muhammad Dailami ${ }^{3)^{*}}$
}

\section{Diterima : 19 Maret 2020 \\ Disetujui : 4 Agustus 2020}

\begin{tabular}{l}
\hline Afiliasi Penulis: \\
1) Jurusan Manajemen \\
Sumberdaya Perairan, Universitas \\
Musamus, Merauke, Indonesia \\
2) Jurusan Perikanan, Universitas \\
Papua, Manokwari, Indonesia \\
3) Program Studi Budidaya \\
Perairan, Fakultas Perikanan dan \\
Ilmu Kelautan, Universitas \\
Brawijaya, Malang, Indonesia \\
\hline Alamat Korespondensi: \\
*muhdailami@ub.ac.id
\end{tabular}

\section{Cara Sitasi:}

Saleky, D., S.P.O. Leatemia, T.F. Pattiasina, Isma, R.D. Pangaribuan, M.A. Welliken, E.H.P. Melmambessy \& M. Dailami. 2020. Analisis pola pertumbuhan dan pendekatan DBA barcoding untuk identifikasi Turbo stenogyrus P. Fischer, 1873 (Mollusca: Gastropoda). Biotropika: Journal of Tropical Biology 8 (2): 79-86.

\section{ABSTRAK}

Pengelolaan dan pelestarian keanekaragaman hayati berawal dari pengetahuan tentang ketersediaan sumberdaya, identifikasi, dan sistematika spesies. Banyaknya spesies Turbinidae dengan berbagai bentuk morfologi dan transformasi bentuk menjadikan identifikasi dengan gen COI sangat penting dalam mempercepat pengungkapan identitas spesies. Penelitian ini dilakukan dengan tujuan menganalisis pola pertumbuhan dan mengidentifikasi gastopoda Turbinidae dengan pendekatan DNA barcode. Hasil identifikasi berdasarkan karakter morfologi menunjukkan bahwa genus Turbo yang diamati adalah dari spesies Turbo stenogyrus. Analisis pola pertumbuhan menunjukkan bahwa pola pertumbuhan T. stenogyrus adalah allometrik negatif. Amplifikasi DNA dengan gen COI menghasilkan panjang sekuen DNA 650 bp dengan hasil identifikasi sesuai dengan pengamatan morfologi yaitu Turbo stenogyrus. Berdasarkan analisis filogenetik dan jarak genetik, sekuen DNA yang dianalisis membentuk clade yang sama dengan spesies Turbo stenogyrus dengan jarak genetik terdekat 4,2\%. Analisis genetik melalui gen COI sangat baik dan memberi kemudahan dalam identifikasi spesies gastropoda.

Kata Kunci: Allometrik negatif, gen COI, jarak genetik, Turbo stenogyrus

ABSTRACT
Conservation and management of biodiversity begins with knowledge of
resource availability, species identification and taxonomy. Many Turbinidae
species with various morphological pattern and its transformation makes the
species identification with COI gene is important to disclosure the species
identity. This research is conducted with aim to analyze the growth pattern and
identification of gastropods turbinidae by using DNA barcoding approach. The
morphological identification result shows that the genus Turbo in this study were
Turbo stenogyrus. Growth pattern analyze explains that T. stenogyrus has
negative allometric growth. The DNA amplification of COI gene produces a total
650 base pairs of DNA sequence with the identification result is T. stenogyrus,
this result is concordance with the morphological data. Based on the
phylogenetic tree and genetic distance data, DNA sekuens of this sample was in
the same clade with T. stenogyrus with 4.2\% genetic distance. Genetic analysis
with COI gene is good and give simplicity in turban snails species identification.

Keywords: COI gene, genetic distance, negative allometric, Turbo stenogyrus

\section{PENDAHULUAN}

Pengelolaan dan pelestarian keanekaragaman hayati berawal dari pengetahuan tentang sumberdaya yang tersedia, sumberdaya yang telah hilang, masalah yang dihadapi serta solusi yang paling efektif dalam identifikasi dan taksonomi [1]. Laju kerusakan lingkungan dan pemanfaatan berlebih dapat berdampak pada terjadinya penurunan populasi dan 
kepunahan yang menyebabkan banyak spesies yang belum terungkap sampai saat ini [2].

Turbinidae dikenal dengan nama bia mata merupakan gastropoda herbivora pemakan alga [3] yang telah dimanfaatkan secara umum di berbagai daerah [4]. Turbinidae sering ditemukan dan melimpah pada daerah intertidal berbatu di pesisir Manokwari [5]. Pola pertumbuhan gastropoda berbeda tiap jenis sebagai akibat dari faktor fisiologis dan juga faktor ekologis [6]. Analisis pola pertumbuhan dilakukan dalam manajemen pengelolaan dan konservasi perikanan seperti penilaian stok dan biomasa [7]. Banyaknya spesies Turbinidae dengan berbagai bentuk morfologi dan transformasi bentuk dalam setiap tahapan kehidupan organisme menjadikan identifikasi berbasis potongan DNA dengan gen COI dapat membantu mempercepat pengungkapan identitas spesies [8], [9].

Gastropoda Turbinidae terdiri dari berbagai spesies yang mirip secara morfologi, kondisi tersebut dapat mengakibatkan terjadinya kesalahan identifikasi. DNA barcode adalah metode identifikasi yang menggunakan sekuen gen pendek yang diambil dari bagian genom organisme yang digunakan dalam studi spesies, ekologi, dan evolusi [10]. DNA barcoding digunakan dalam mengidentifikasi secara cepat, tepat, dan mengurangi kesulitan dalam mengidentifikasi spesies [11], penting dalam menghubungkan sejarah kehidupan spesies [12]. Identifikasi dengan pendekatan molekuler telah banyak dilakukan pada beberapa jenis gastropoda seperti Turbinidae [3], Turbo sp. [13], Telescopium telescopium [14].

Turbinidae memiliki keanekeragaman spesies yang sangat tinggi, yang menyebabkan terjadinya banyak masalah dalam taksonomi, Identifikasi gastropoda pada umumnya menggunakan karakter cangkang untuk membedakan antara spesies Gastropoda tetapi identifikasi berdasarkan cangkang saja tidak cukup mengingat karakter cangkang dapat berubah akibat dari beberapa faktor seperti perubahan lingkungan [15], perubahan bentuk dan warna [16]. Selain karakter morfologi pada cangkang, identifikasi spesies biasanya juga dapat dibedakan dengan menggunakan karakter anatomi yang lebih stabil [17]. Namun pengamatan karakter anatomi yang membutuhkan tahapan pembedahan seringkali menyulitkan. Kondisi-kondisi tersebut, menyebabkan identifikasi dengan DNA barcoding menjadi salah satu alternatif metode yang penting dilakukan, karena hasilnya memiliki tingkat akurasi yang tinggi [18].

Kurangnya informasi tentang Turbo sp. khususnya dalam penentuan spesies menjadikan pengelolaan suatu sumberdaya menjadi tidak maksimal. Sehingga analisis pola pertumbuhan dan identifikasi dengan DNA barcoding sangat penting dalam kegiatan pengelolaan dan pengungkapan identitas spesies secara cepat, tepat, dan akurat [19].

\section{METODE PENELITIAN}

Koleksi sampel dan pengukuran morfometrik. Pengambilan sampel Turbo sp. dilakukan saat surut terendah, di pesisir Pantai Yekwandi, Distrik Momiwaren, Kabupaten Manokwari Selatan.

Sampel dikoleksi pada saat malam hari karena jenis Gastropoda tersebut adalah jenis nokturnal yang aktif pada malam hari [20]. Sampel kemudian diidentifikasi secara morfologi dengan menggunakan buku identifikasi Gastropoda Recent and Fossil Indonesian Shells [19]. Panjang cangkang dan berat total gastropoda diukur dengan menggunakan kaliper dan timbangan digital. Selain itu, dilakukan pula pengambilan jaringan kaki perut yang disimpan dalam tube berisi ethanol 95\% untuk keperluan analisis molekuler.

Analisis molekuler. Analisis molekuler dilakukan di Sub Laboratorium Genetika, Fakultas Perikanan dan Ilmu Kelautan Universitas Papua Manokwari. Isolasi DNA dari jaringan kaki perut dengan menggunakan extraction kit (Geneid $^{\mathrm{TM}}$ DNA Isolation Kit (tissue)). Amplifikasi gen COI dilakukan dengan menggunakan Go taq green Amplitaq (Promega) dengan total reaksi adalah $50 \mu \mathrm{l}$ yang terdiri dari $\mathrm{ddH}_{2} \mathrm{O}(18 \mu \mathrm{l})$, go taq green $(25 \mu \mathrm{l})$, primer forward JgLCO1490 $(2.5 \mu 1)$ dan reverse JgHCO2198 (2.5 $\mu$ l) [21], ekstrak DNA $(5 \mu \mathrm{l})$, DMSO $(1 \mu \mathrm{l})$ dan BSA $(1 \mu \mathrm{l})$. Adapun sekuens primer yang digunakan yaitu jgLCO1490 5'-TITCIACIAAYCAYAARGA YATTGG-3' dan juga HCO2198 5'TAIACYTCI GGRTGICCRAARAAYCA-3' [21]. Hasil PCR yang teramplifikasi positif kemudian dikirim untuk disekuensing di perusahaan jasa sekuensing yaitu 1st Base Malaysia.

Analisis data. Pola pertumbuhan Gastropoda Turbo sp. dilakukan analisis regresi linear dengan menggunakan Microsoft Excel 2010 dengan formula [16]: 


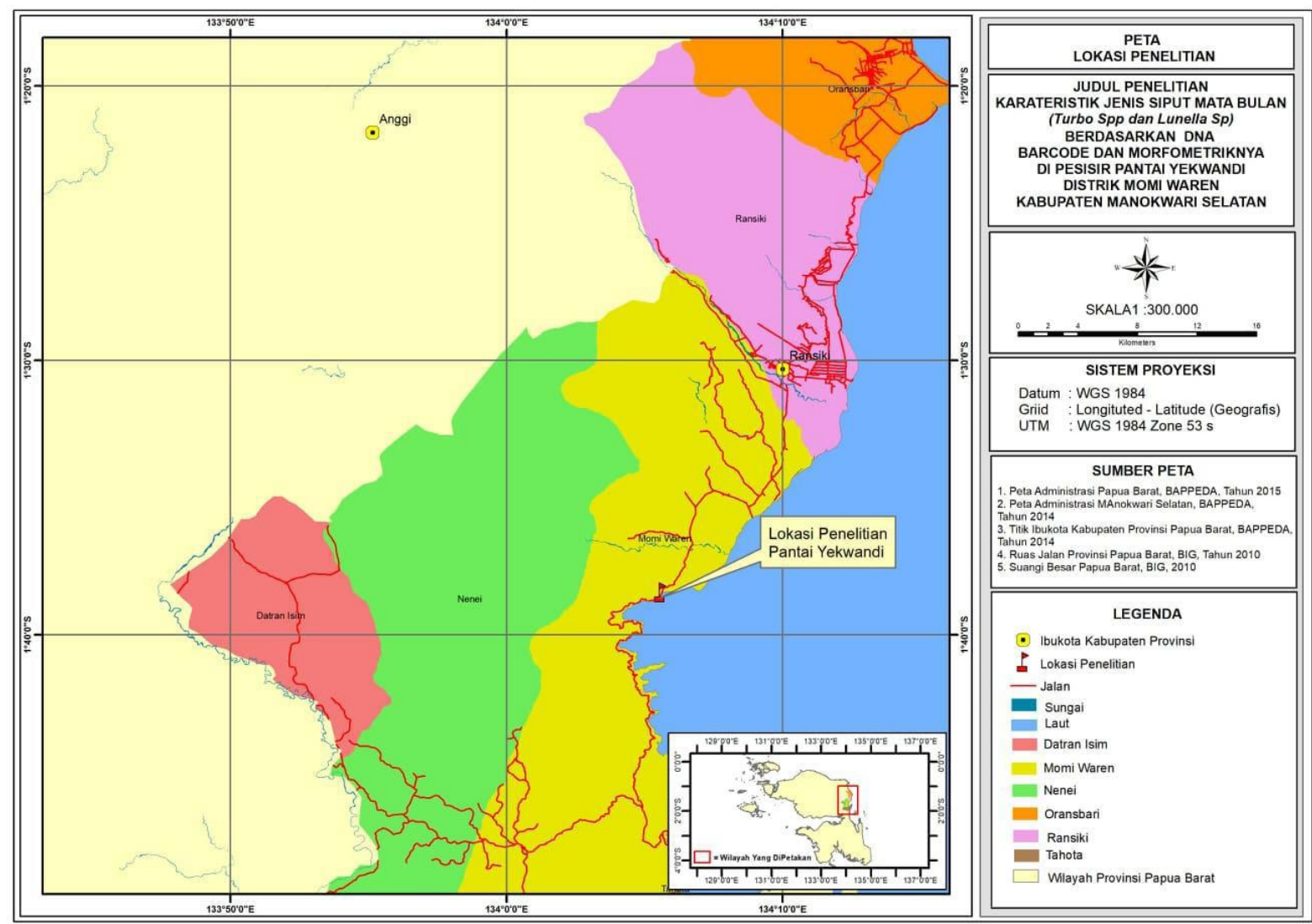

Gambar 1. Lokasi pengambilan sampel Turbo stenogyrus di Pesisir Pantai Yekwandi Distrik Momiwaren Kabupaten Manokwari Selatan (Sumber: Dokumen Penulis)

Tabel 1. Sekuen DNA T. sparverius, T. bruneus, T. setosus, T. stenogyrus dan Lunella sp. yang digunakan dalam rekontruksi filogenetik termasuk lokasi, nomor akses dari National Center for Biotechnology Information (NCBI)

\begin{tabular}{lllc}
\hline Spesies & Lokasi & Acc. Number & Sumber \\
\hline T. bruneus & Asai & MK273558.1 & {$[3]$} \\
T. bruneus & Rendani & MK273557.1 & {$[3]$} \\
T. bruneus & Sabah, Malaysia & AM403981 & {$[24]$} \\
T. bruneus & Sabah, Malaysia & AM403929 & {$[24]$} \\
T. bruneus & St. Johnos Island, Singapura & AM403929 & {$[24]$} \\
T. bruneus & St. Johnos Island, Singapura & AM049381 & {$[24]$} \\
T. setosus & Pulau Mansinam & - & {$[13]$} \\
T. sparverius & Asai & - & {$[13]$} \\
T. stenogyrus & Japan & AM403916.1 & {$[24]$} \\
Lunella sp. & Manokwari selatan & - & - \\
\hline
\end{tabular}

$\mathrm{W}=\mathrm{aL}^{\mathrm{b}}$

Keterangan:

W : berat total (termasuk cangkang)(gram)

L : Panjang total (mm)

a dan b: Konstanta

Nilai b menggambarkan pola pertumbuhan spesies, jika nilai $b=3$ menggambarkan pertumbuhan isometrik. Sedangkan jika nilai $b$ $\neq 3$ menggambarkan pertumbuhan spesies adalah allometrik [22].
Hasil sekuensing yang didapat kemudian diedit dan diurutkan dengan menggunakan model ClustalW (1.6) [23] pada program MEGA 7 (Moleculer Evolutionary Genetic Analysis). Data hasil sekuen nukleotida yang telah diedit kemudian dicocokkan dengan data yang tersedia pada GenBank di NCBI (National Center for Biotechnology Information) (https://www.ncbi. nlm.nih.gov/) dengan menggunakan BLAST (Basic Local Alignment Search Tool) dan Boldsystem (http://www.boldsystems.org). 
Analisis filogenetik menggunakan metode Neighbor-Joining (NJ) dengan model Kimura 2-parameter, bootstrap 1000x yang dibentuk dari beberapa sekuen DNA yang diambil dari NCBI dan juga sekuen hasil penelitian sebelumnya sebagai sekuen pembanding dalam penelitian ini (Tabel 1).

\section{HASIL DAN PEMBAHASAN}

Identitas spesies Turbo berdasarkan pengamatan morfologi. Keong Turbo yang berhasil dikoleksi memiliki ciri-ciri yaitu memiliki cangkang yang keras, kasar bergerigi dan memanjang dengan operculum berwarna putih ataupun putih kehitaman. Warna cangkang hijau dan hitam keclokatan dengan kisaran ukuran 14,55-58,53 mm. Berdasarkan ciri-ciri tersebut diyakini bahwa seluruh keong yang dikoleksi adalah spesies Turbo stenogyrus.

Pola pertumbuhan Turbo stenogyrus. Total 57 individu T. stenogyrus dikoleksi dari pesisir Pantai Yekwandi, Distrik Momiwaren, Kabupaten Manokwari Selatan. Pengukuran morfometrik meliputi panjang cangkang dan berat total. Ukuran panjang cangkang berkisar antara $14,55-58,53 \mathrm{~mm}$ dengan berat total berkisar 3,7-41,5 g.

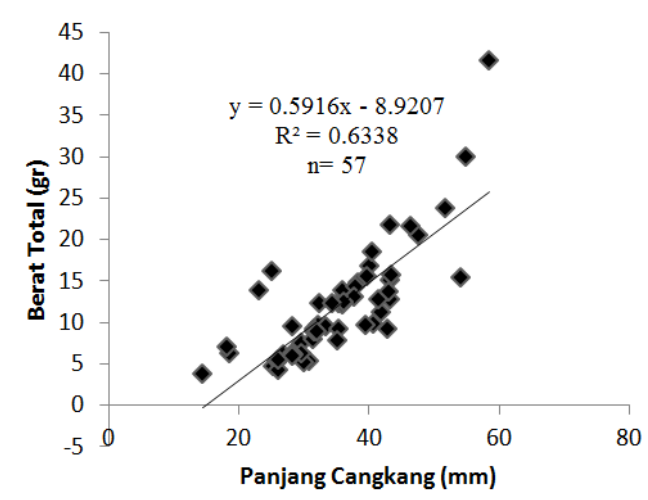

Gambar 1. Regresi linear panjang total dan berat total dari 57 individu T. stengyrus

Gastropoda Turbinidae seperti $T$. stenogyrus adalah jenis gastropoda pemakan alga yang umumnya ditemukan pada daerah rataan terumbu karang maupun intertidal berbatu. Spesies T. stenogyrus memiliki kemiripan morfologi dengan spesies $T$. bruneus, yang telah dikoleksi sebelumnya pada beberapa lokasi di daerah Kepala Burung Papua [3], [13]. T.stenogyrus memiliki bentuk morfologi yang mirip dengan $T$. bruneus karakter morfologi yang mirip dari bentuk, ukuran dan warna cangkang dan juga keduanya memiliki habitat yang sama yaitu pada intertidal berbatu.

Pola pertumbuhan $T$. stenogyrus dengan persamaan $\mathrm{W}=1.2003 \mathrm{~L}^{0.5916}$ dengan nilai $\mathrm{R}^{2}=$ $\mathrm{R}^{2}=0,634$. Analisis panjang dan berat menunjukkan hubungan linier dengan persamaan garis $\mathrm{Y}=0,5916 \mathrm{x}-8,9207$. Berdasarkan nilai korelasi yang diperoleh, kontribusi panjang cangkang terhadap berat adalah 0,796147. Hasil analisis pola pertumbuhan didapat nilai sebesar 0,5916 (b>3). Hasil tersebut menunjukkan bahwa pola pertumbuhan $T$. stenogyrus adalah allometrik negatif, yang berarti pertambahan berat badan lebih lambat daripada panjangnya [3]. T.stenogyrus memiliki bantuk cangkang yang relatif kurus. Nilai allometrik negatif pada suatu spesies diidentikan dengan bentuk tubuh yang kurus [25].

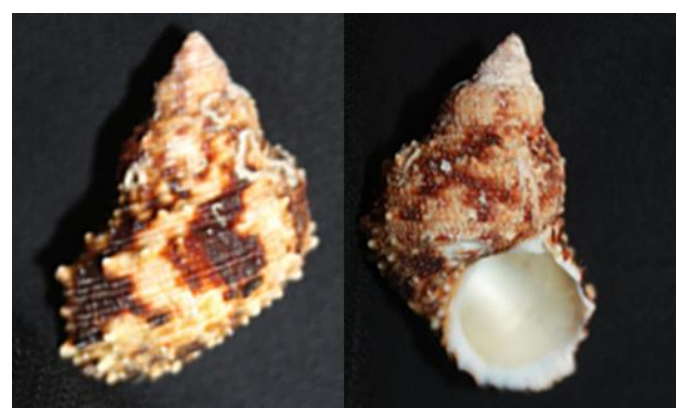

Gambar 2. Morfologi Turbo stenogyrus asal Manokwari selatan

Hasil tersebut banyak dijumpai pada berbagai jenis gastropoda seperti $T$. spaverius (nilai $\mathrm{b}=2.467$ ), $T$. bruneus (nilai $\mathrm{b}=2.295$ ) [3], Telescopium telescopium (nilai $b=1.14$ ) [6], dan berbagai jenis gastropoda air tawar [26].

Karakteristik molekuler. Panjang hasil amplifikasi PCR gen COI dari T. stenogyrus dengan menggunakan primer JgLCO1490 dan JgHCO2198 adalah 650 bp (base pair). Panjang hasil amplifikasi DNA yang didapatkan sama dengan hasil yang diperoleh pada analisis Gastropoda Turbinidae [3], [13].

Identifikasi spesies menggunakan analisis BLAST pada NCBI memperoleh hasil kemiripan sekuen sebesar 96,13\% dan 95,97 $\%$ hasil identifikasi menggunakan Bold System (http://www.boldsystems.org) menunjukkan bahwa adalah benar bahwa keong Turbinidae yang diteliti adalah spesiesTurbo stenogyrus. 


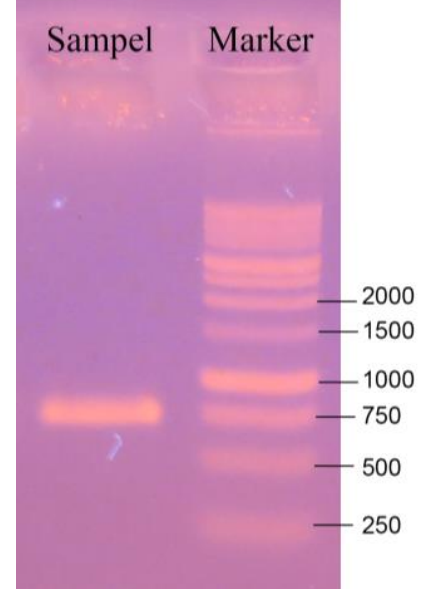

Gambar 3. Hasil ampilifikasi gen COI Turbo stenogyrus

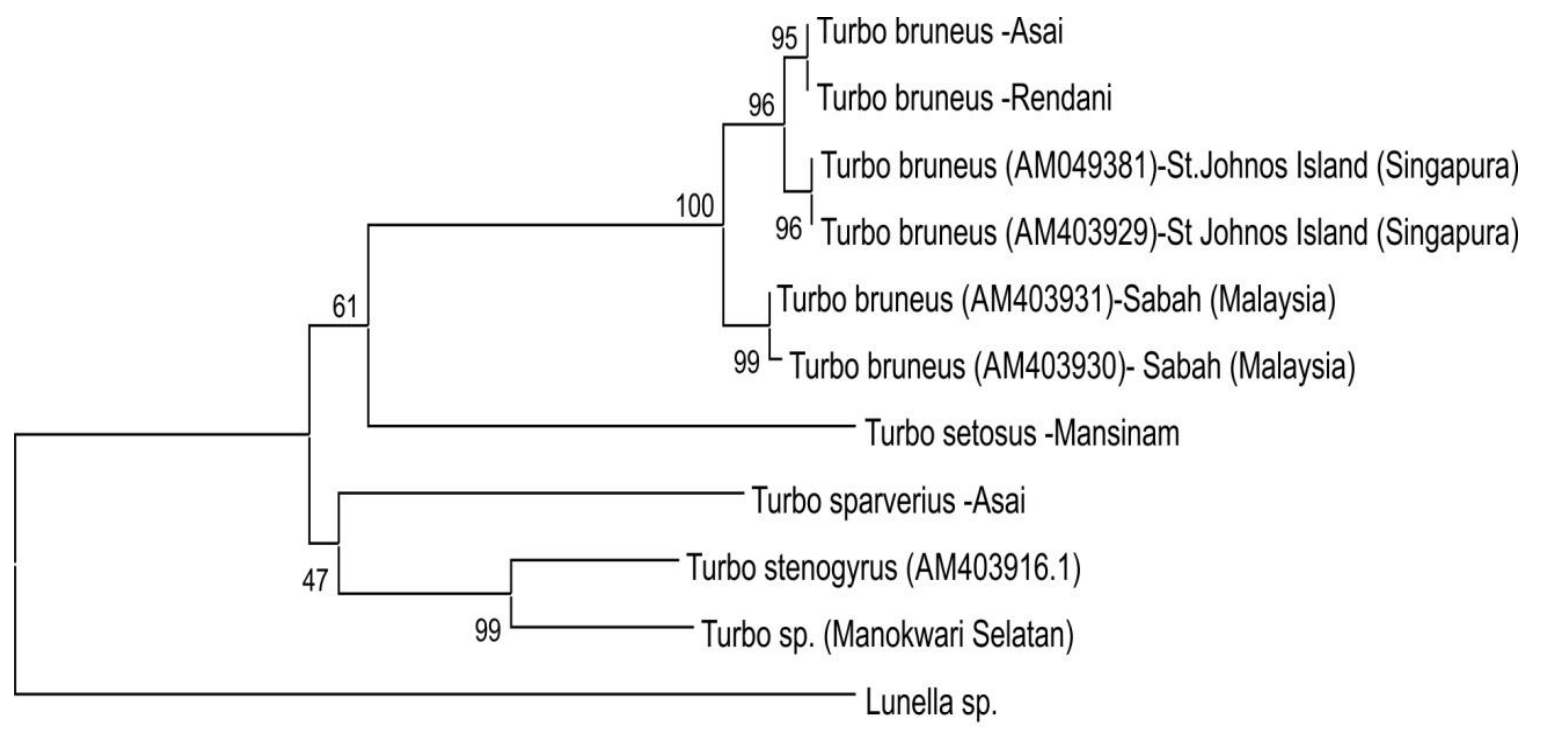

0.02

Gambar 4. Pohon filogenetik Turbo sp. menggunakan metode Neighbor-Joining (NJ) dengan model Kimura 2-parameter, bootstrap 1000 replikasi. Angka di setiap cabang menunjukkan nilai bootstrap yang diperoleh.

Spesies yang mirip secara morfologi (cryptic) sering terjadi pada spesies invertebrata, sehingga identifikasi molekuler dan konvensional dilakukan secara bersama sehingga dapat mengungkap keanekeragaman spesies secara cepat dan akurat [27]. Hasil analisis molekuler diperoleh panjang sekuen DNA adalah $650 \mathrm{bp}$, panjang sekuen tersebut umum diperoleh pada sekuen COI pada Turbinidae [3], [13].

Pohon filogenetik Turbo sp. asal Manokwari Selatan (Gambar 4) memperlihatkan Turbo sp. asal Manokwari Selatan berada dalam satu clade dengan $T$. stenogyrus dengan nilai bootstrap 99. Sedangkan T. bruneus yang memiliki kemiripan morfologi dengan $T$. stenogyrus berada pada clade yang berbeda bersama $T$. setosus. Pada organisme laut, keragaman, dan diferensiasi genetik sangat dipengaruhi oleh respon adaptasi organisme terhadap kondisi lingkungan [28], interaksi kompleks antar dinamika oseanografi dan sifat ekologis [29].

Tingginya nilai bootstrap yang terbentuk mengindikasikan percabangan pada pohon filogenetik yang terbentuk memiliki tingkat validitas dari percabangan tersebut. Dengan didukung oleh nilai bootstrap yang tinggi dan sangat stabil, dengan demikian semakin tinggi nilai bootstrap maka kestabilannya makin baik [30]. 
Tabel 2. Jarak genetik antara Turbo stenogyrus asal Manokwari Selatan dengan beberapa sekuen yang diambil dari GenBank

\begin{tabular}{|c|c|c|c|c|c|c|c|c|c|c|}
\hline No & Spesies & 1 & 2 & 3 & 4 & 5 & 6 & 7 & 8 & 9 \\
\hline 1 & Turbo bruneus (Asai) & - & & & & & & & & \\
\hline 2 & Turbo bruneus (Rendani) & 0,000 & - & & & & & & & \\
\hline 3 & $\begin{array}{l}\text { Turbo bruneus (AM049381)- } \\
\text { St.Johnos Island (Singapura) }\end{array}$ & 0,006 & 0,006 & - & & & & & & \\
\hline 4 & $\begin{array}{l}\text { Turbo bruneus } \\
\text { (AM403931) - Sabah } \\
\text { (Malaysia) }\end{array}$ & 0,016 & 0,016 & 0,016 & - & & & & & \\
\hline 5 & $\begin{array}{l}\text { Turbo bruneus } \\
\text { (AM403930) - Sabah } \\
\text { (Malaysia) }\end{array}$ & 0,017 & 0,017 & 0,017 & 0,002 & - & & & & \\
\hline 6 & $\begin{array}{l}\text { Turbo bruneus (AM403929) - } \\
\text { St Johnos Island (Singapura) }\end{array}$ & 0,006 & 0,006 & 0,000 & 0,016 & 0,017 & - & & & \\
\hline 7 & Turbo sparverius (Asai) & 0,108 & 0,108 & 0,112 & 0,104 & 0,106 & 0,112 & - & & \\
\hline 8 & Turbo setosus (Mansinam) & 0,110 & 0,110 & 0,110 & 0,106 & 0,108 & 0,110 & $0,122 *$ & - & \\
\hline 9 & $\begin{array}{l}\text { Turbo stenogyrus } \\
\text { (AM403916) }\end{array}$ & 0,104 & 0,104 & 0,104 & 0,093 & 0,095 & 0,104 & 0,090 & 0,107 & - \\
\hline 10 & $\begin{array}{l}\text { Turbo sp. (Manokwari } \\
\text { Selatan) }\end{array}$ & 0,108 & 0,108 & 0,108 & 0,101 & 0,102 & 0,108 & 0,088 & 0,101 & 0,042 \\
\hline
\end{tabular}

*Jarak genetik terbesar

Pohon filogenetik (Gambar 2) T. stenogyrus asal Manokwari Selatan dengan sekuen tambahan dari Genbank dan sekuen dari penelitian sebelumnya. $T$. stenogyrus membentuk clade tersendiri berbeda dengan clade T. bruneus. Secara morfologi T. bruneus memiliki kemiripan dengan $T$. stenogyrus tetapi berdasarkan analisis pohon filogenetik kedua spesies tersebut terpisah dan masing masing membentuk clade tersendiri. Pohon filogenetik menunjukkan pengelompokan antar sekuen individu. Pohon filogenetik berdasarkan data sekuen adalah hal yang terpenting dan menarik dalam studi evolusi [31]. Pohon filogenetik membentuk grafik dua dimensi yang menunjukkan hubungan di antara organisme atau lebih.

Rekonstruksi pohon filogenetik didukung oleh analisis jarak genetik (Tabel 2), jarak genetik terendah $0,00 \%$ antara $T$. bruneus (Asai) dan T. bruneus (Rendani) dan tertinggi 12,2\% antara $T$. setosus (Mansinam) dan $T$. sparverius (Asai). Sedangkan jarak genetik antar T. bruneus dan Turbo sp. asal Manokwari Selatan memiliki jarak genetik 10,8\% hal tersebut mengindikasikan spesies yang dikoleksi dari dari pesisir Manokwari Selatan bukanlah jenis $T$. bruneus meskipun memiliki kemiripan morfologi. Jarak genetik terdekat Turbo sp. asal Manokwari Selatan adalah dengan jenis $T$. stenogyrus dengan jarak genetik $4,2 \%$.

\section{KESIMPULAN}

Pola pertumbuhan Turbo stenogyrus adalah allometrik negatif, yang berarti pertambahan berat lebih lambat daripada panjang. Berdasarkan analisis filogenetik dan jarak genetik, sekuen DNA yang dianalisis membentuk clade yang sama dengan spesies $T$. stenogyrus dengan jarak genetik terdekat $4,2 \%$. Analisis molekuler memperlihatkan jenis tersebut adalah jenis T. stenogyrus. Analisis genetik melalui gen CO1 sangat baik dan memberi kemudahan dalam identifikasi spesies gastropoda.

\section{UCAPAN TERIMA KASIH}

Ucapan terimakasih disampaikan kepada Laboratorium Genetika Molekuler, FPIK, Universitas Papua yang telah memfasilitasi pelaksanaan penelitian ini sehingga dapat berjalan dengan baik.

\section{DAFTAR PUSTAKA}

[1] Ji Y, Ashton L, Pedley SM, Edwards DP, Tang Y, Nakamura, A, Kitching, R, Dolman PM, Woodcock P, Edwards FA, Larsen TH, Hsu WW, Benedick S, Hamer $\mathrm{KC}$, Wilcove DS, Bruce C, Wang X, Levi T, Lott M, Emerson BC, Yu DW (2013) Reliable, verifiable and efficient monitoring of biodiversity via 
metabarcoding. Ecol. Lett. 16 (10): 12451257. doi: 10.1111/ele. 12162.

[2] Jala S, Haumahu S, Uneputty P (2014) Variasi morfometrik dan hubungan panjang berat siput jala. Jurnal TRITON 10: $122-130$.

[3] Saleky D, Setyobudiandi I, Toha AHA, Takdir M, Madduppa HH (2016) Lengthweight relationship and population genetic of two marine gastropods species (Turbinidae: Turbo sparverius and Turbo bruneus) in the bird seascape Papua, Indonesia. Biodiversitas J. Biol. Divers. 17 (1): 208-217. doi: 10.13057/biodiv/d170 130.

[4] Watson G, Davies J, Wood H, \& Cocks A (2018) A comparison of survivorship and function (grazing and behaviour) of three gastropod species used as clean-up crew for the marine aquarium trade. PLoS One 13 (6): 1-16. doi: 10.1371/journal.pone.0199516.

[5] Saleky D, Leatemia SP, Yuanike Y, Rumengan I, Putra ING (2019) Temporal distribution of G astropods in rocky intertidal area in North Manokwari, West Papua. Jurnal Sumberdaya Akuatik Indopasifik 3 (1): 1$10 . \quad$ doi: $10.46252 /$ jsai-fpikunipa.2019.Vol.3. No.1.58.

[6] Ariyanto D, Bengen DG, Prartono $T$ (2018) Length-Weight relationships and condition factors of Telescopium telescopium (Gastropoda: Potamididae) in Banggi coast of Central Java, Java Island, Indonesia. International Journal of Fisheries and Aquatic Studies 6 (2): 548550.

[7] Ayoade AA, Ikulala AOO (2007) Length weight relationship, condition factor and stomach contents of Hemichromis bimaculatus, Sarotherodon melanotheron and Chromidotilapia guentheri (Perciformes: Cichlidae) in Eleiyele Lake, Southwestern Nigeria. Rev. Biol. Trop. 55 (3-4): 969-977. doi: 10.1551 7/rbt.v55i34.5970.

[8] Hebert PDN, Ratnasingham S, deWaard JR, Hebert PDN, Ratnasingham S, \& Jeremy R (2003) Barcoding animal life: cytochrome c oxidase subunit 1 divergences among closely related species. Proc Biol Sci. 270 (Suppl 1): S96-S99. doi: 10.1098/rsbl.2003.0025

[9] Hebert PDN, Cywinska A, Ball SL, deWaard JR (2003) Biological identifications through DNA barcodes.
Proc Biol Sci. 270 (1512): 313-321. doi: 10.1098/rspb.2002.2218

[10] Kress WJ, García-Robledo C, Uriarte M, Erickson DL (2015) DNA barcodes for ecology, evolution, and conservation, Trends Ecol. Evol. 30 (1): 25-35. doi: 10.1016/j.tree.2014.10.008.

[11] Madduppa H, Taurusman AA, Subhan B, Anggraini NP, Fadillah R, Tarman K (2017) Short communication: DNA barcoding reveals vulnerable and not evaluated species of sea cucumbers (Holothuroidea and Stichopodidae) from Kepulauan Seribu reefs, Indonesia. Biodiversitas 18 (3): 893-898. doi: 10.13057/biodiv/d180305.

[12] Puillandre N, Strong EE, Bouchet P, Boisselier MC, Couloux A, Samadi S (2009) Identifying gastropod spawn from DNA barcodes: possible but not yet practicable. Mol. Ecol. Resour. (9) 5: 1311-1321. doi: 10.1111/j.17550998.2009.02576.x

[13] Leatemia SPO, Manumpil AW, Saleky D, Dailami M (2018) DNA Barcode dan Molekuler Filogeni Turbo sp. di Perairan Manokwari Papua Barat. Prosiding Seminar Nasional MIPA Unipa 3: 103114.

[14] Palanisamy SK, Kumar CP, Paramasivam P, Sundaresan U (2018) Molecular Approach to the identification and phylogenetic biogeography of snail Telescopium telescopium using mt-COI gene sequences. Regional Studies in Marine Science 35: 1-17. doi: 10.1016/j.rsma.2020.101109

[15] Razkin O, Gómez-Moliner BJ, Vardinoyannis K, Martínez-Ortí A, Madeira MJ (2017) Species delimitation for cryptic species complexes: case study of Pyramidula (Gastropoda, Pulmonata)," Zool. Scr. 46(1): 55-72. doi: 10.1111/zsc. 12192

[16] Tindi M, Mamangkey NGF, Wullur S, (2017) DNA barcode dan analisis filogenetik molekuler beberapa jenis bivalvia asal perairan Sulawesi Utara berdasarkan gen COI. Jurnal Pesisir dan Laut Tropis. 1(2): 32-38.

[17] Puillandre N, Cruaud C, Kantor YI (2010) Cryptic species in Gemmuloborsonia (Gastropoda: Conoidea). Journal Molluscan Study 76(1): 11-23. doi: 10.1111/j.1755-0998.2009.02576.x.

[18] Layton KKS, Martel AL, Hebert PD (2014) Patterns of DNA barcode variation 
in Canadian marine molluscs. PLoS One 9 (4): e95003. doi: 10.1371/journal.pone.00950 03.

[19] Purnamasari L, Farajallah A, Wowor D (2016) Application of DNA barcode in determination of shrimp species of fresh water from the Province of Jambi. BioCENCETTA II (1): 50-59.

[20] Alf A, Kreipl K (2015) A new species of the family Turbinidae Rafinesque, 1815 from Saint Brandon, Western Indian Ocean (Mollusca, Gastropoda, Vetigastropoda, Turbinidae). Spixiana 38(1): 3-10.

[21] Geller J, Meyer C, Parker M, Hawk H (2013) Redesign of PCR primers for mitochondrial cytochrome c oxidase subunit I for marine invertebrates and application in all-taxa biotic surveys. Molecular Ecolology Resources 13(5): 851-861. doi: 10.1111/1755-0998.12138.

[22] Effendie MI (1979) Method on fish biology. IPB, Bogor, Yayasan Agromedia.

[23] Kumar S, Stecher G, Tamura K (2016) MEGA7: Molecular evolutionary genetics analysis version 7.0 for bigger datasets. Molecular Biology Evolution 33(7) 18701874. doi: $10.1093 / \mathrm{molbev} / \mathrm{msw} 054$.

[24] Williams ST (2007) Origins and diversification of Indo-West Pacific marine fauna: evolutionary history and biogeography of turban shells (Gastropoda, Turbinidae). Biol. J. Linn. Soc. 92(3): 573-592. doi: 10.1111/j.10958312.2007.0085 4.x.

[25] Zabarun A (2016) Hubungan panjang berat, faktor kondisi dan rasio berat daging Kerang Pasir (Modiolus modulaides) di perairan Bungkutoko Kota Kendari. Jurnal Manajemen Sumberdaya Perairan 2(1): 21-32.

[26] Krupanidhi S (2020) Regression analysis of shell morphology of a few of endemic aquatic and terrestrial gastropods as a prelude to their conservation strategy. Acta Scientific Biotechnology 1(1): 2-7.

[27] Vrijenhoek RC (2009) Cryptic species, phenotypic plasticity, and complex life histories: Assessing deep-sea faunal diversity with molecular markers. Deep Sea Res. Part II Top. Stud. Oceanogr. 56 (19-20): 1713-1723. doi: 10.1016/J. DSR2.2009.05.016.

[28] Solas M, Sepúlveda R, Brante A (2013) Genetic variation of the shell morphology in Acanthina monodon (Gastropoda) in habitats with different wave exposure conditions. Aquat. Biol. 18(3): 253-260. doi: 10.3354/ab00508

[29] Silva SE, Silva IC, Madeira C, Sallema R, Paulo OS, Paula J (2013) Genetic and morphological variation in two littorinid gastropods: evidence for recent population expansions along the East African coast. Biol. J. Linn. Soc. 108(3): 494-508 doi: $10.1111 /$ j.1095-8312.20 12.02041.x.

[30] Wirdateti W, Indriana E, Handayani H, (2016) Analisis sekuen DNA mitokondria cytochrome oxidase I (COI) mtDNA pada Kukang Indonesia (Nycticebus spp) sebagai penanda guna pengembangan identifikasi spesies Jurnal Biologi Indonesia 12(1): 119-128. doi: 10.14203/jbi.v12i1 .2322.

[31] Indi DNLP (2011) Filogenetika molekuler: Metode taksonomi organisme berdasarkan sejarah evolusi. Wartazoa 30(16114): 1-10. 